\title{
ДЖЕРЕЛА ПРАЦІ ГВІДО ДЕ БАТТАЛІЇ ПРО ТАРАСА ШЕВЧЕНКА
}

\author{
Роксана Харчук \\ Відділ шевченкознавства, Інститут літератури ім. Т. Г. Шевченка НАН України \\ Київ, Україна \\ ORCID ID: 0000-0003-1039-1319
}

\section{THE SOURCES OF GUIDO DE BATTALIA'S WORK ON SHEVCHENKO}

\begin{abstract}
The article clarifies the first printing of Battaglia's work about Taras Shevchenko's life and poetry. Before being published as a separate print, it was published under the title «Shevchenko, Ukrainian poet» in the 1-7, 9-11, 13-18 issues of «Tygodnik Naukowy», Lviv, in 1865 . The article explores the sources used by a Polish critic. The author concludes that, in relation to the limited biographical and literary material on the subject of Shevchenko and his poetry, de Battaglia showed independence of thinking and objectivity of judgments on the basis of Shevchenko's poems, including those were banned in Russia. His work is both - informative and polemical. The critic argued particulary with F. Falensky, partly with L. Sovinsky, being in solidarity with J. Liam on the formation of the new Ukrainian identity and on the issue of Shevchenko's importance in this process. Despite a number of mistakes and inaccuracies, a new generation of Galician Ukrainians in the 1860s became acquainted with Shevchenko's life and poetry from Battaglia's work.
\end{abstract}

Keywords: G. De Battalia, Shevchenko, first Shevchenko's biography, literary portrait, sources, informative and polemical character, Ukrainian identity

Праця Гвідо де Батталії Тарас Шевченко, його життя і твори побачила світ у Львові 1865 р., коли галицькі українці щойно познайомилися із творчістю поета, його текстів хронічно бракувало, тому їх переписували від руки. Автор поставив собі за мету поінформувати передусім поляків про творчість українського мистця, повсякчас наголошуючи на польській темі у його поезії, розглянув тогочасні польські переклади Шевченка, виконані Антонієм Гожалчинським, Владиславом Сирокомлею та Леонардом Совінським. Цю розвідку, яку з повним правом можна назвати літературним портретом ${ }^{1}$, адже в ній творчість Шевченка розгля-

1 В. Смілянська визначила жанр цієї праці як критико-біографічний нарис. Див: В. Смілянська, Біографічна шевченкіана (1861-1981), Київ 1984, с. 38. 
дається на тлі його біографії і у зв'язку з нею, барон написав одразу після розгрому Січневого повстання 1863-1864 pр., в якому брав безпосередню участь. На мою думку, цей факт біографії критика сприяв адекватному прочитанню і розумінню поета, яке у тодішньому польському середовищі не було домінуючим, але й екстраординарним його не назвеш. Досить згадати, що в Петербурзі за упокій поета молилися студенти-поляки, а на самому похороні промову польською мовою виголосив Владислав Хорошевський. Г. де Батталія міг прочитати це прощальне слово у часописі "Основа". Однак він не згадав В. Хорошевського, хоча й посилався на промови Пантелеймона Куліша, Василя Білозерського й Олександра Афанасьєва-Чужбинського. Цей факт схиляє до думки, що критик ознайомився зі статтею Ксенофонта Климковича, що була написана на підставі матеріалу Льва Жемчужникова, але без промов В. Хорошевського і М. Костомарова ${ }^{3}$.

Поляки, що розуміли значення Шевченка у формуванні нової української ідентичності, віддавали належне його талантові, називаючи українським пророком. Вони ладні були забути криваве польсько-українське минуле заради польсько-українського союзу у майбутній боротьбі 3 Російською імперією. Цю думку у 4 числі львівської газети "Dziennik Literacki” за 1863 р. чітко артикулював Ян Лям. Про українську ідею Шевченка він писав так: „...нехай тільки ця ідея набуде виразніших рис, ми побачимо, що вона стане для нас стійкішим союзом, ніж урочисті угоди та споконвічні традиції'4. У відповідь на цю тезу у тій же газеті з'явилося кілька анонімних публікацій, в яких або заперечувалася можливість ставити Шевченка поряд із Зигмунтом Красінським ${ }^{5}$, як це зробив Данило Танячкевич, або твердилося, наче найактивніші народники і творці “гайдамацької школи” П. Куліш і Шевченко не залишать по собі нічого позитивного й не знайдуть співчуття в народі ${ }^{6}$. У питанні Шевченкової творчості й українського майбутнього Г. де Батталія солідаризувався із Я. Лямом й львівськими семінаристами. Він зацікавився віршами Шевченка і матеріалами про поета, які зібрав семінарист Гнат Рожанський, видавець Поезї̈ Тараса Шевченка у двох томах накладом Корнила Сушкевича, що побачила світ у 1867-1868 рр. I Валерія Смілян-

\footnotetext{
2 Л. Жемчужников, Воспоминание о Шевченке, его смерти и погребении, "Основа" 1861, № 3, c. 9 .

3 Кс. Кл, Згадка за Шевченка; его смерть и похороны: Поิсля Л. Жемчужникова, "Вечерниці” 1862, № 22, с. 193-197.

4 Я. Лям, Ще одне слово про Шевченка, [в:] Рецепція творчості Тараса Шевченка в Польщі: у 3 кн., ред. та упор. Р. Радишевський, кн. 1, Київ 2015, с. 118

5 Шевченко поряд із Красінським, цит праця, с. 112.

6 Народ і шляхта на Русі, цит праця, с. 113
} 
ська ${ }^{7}$, і Євген Нахлік ${ }^{8}$ зауважують, що саме за спонукою Гната Гвідо й написав свою працю, присвятивши ії педагогові Болеславу Барановському (1844-1916). Імпульсом до появи зазначеної роботи слугувала дискусія про Шевченка на сторінках газети "Dziennik Literacki” у 1861-1863 p., яку найповніше дослідив $€$. Нахлік9.

Уже на початку своєї праці Г. де Батталія перелічив усі доступні йому джерела до біографії і творчості українського поета: публікації Шевченкових творів під назвою Гостинець кобзаря в альманаху “Хата" (1860), часопис "Основа" (1861-1862), журнал “Вечерниці" (1862-1863), рукопис поеми Сон - У всякого своя доля, праця Леонарда Совінського Тарас Шевченко з додатком поеми “Гайдамаки”, вступ Антонія Гожалчинського до книжки його перекладів з Шевченка, щоденник Якуба Гордона, зокрема уміщена там згадка Солдат. Польському критику була відома рецензія Феліціана Фаленського на працю Л. Совінського, біографічні статті про Шевченка О. Лазаревського і М. Чалого з “Основи” й автобіографія Шевченка у формі листа до редактора журналу “Народное чтение”, відредагована П. Кулішем, у перекладі Л. Совінського, листи Шевченка до Варфоломія Шевченка (1859-1861), листування Шевченка з Я. Кухаренком, зокрема лист до останнього від 1 квітня 1854 р. Г. де Батталія звертався до Кобзаря 1840 р. і 1860 р. 3 огляду на недостатність біографічного матеріалу головне своє завдання вбачав в ознайомленні читачів із творами поета, передусім з ідеями, що проходять через кожний твір.

Праця Тарас Шевченко, його життя і твори відіграла важливу роль в популяризації імені і творчості Шевченка в українській Галичині. Олександр Барвінський зазначив, що тернопільська молодь довідалася про життя Шевченка із польськомовної праці Гвідо де Батталії, яку 1865 р. 3 львівського часопису "Tygodnik Naukowy" видрукували окремим відбитком учасники польського академічного кружка у Львові ${ }^{10}$. Першодрук під назвою Шевченко, украӥнський поет було вміщено у 1-7, 9-11, 13-18 номерах згаданого часопису за 1865 р. Про значення цієї праці для ознайомлення галицької української молоді з життям і творчістю українського мистця згадав також Віктор Петрикевич ${ }^{11}$.

\footnotetext{
7 В. Смілянська, Батталія Гвідо де, [в:] Шевченківська енциклопедія: в 6 m., т. 1, Київ 2013 , c. 345.

8 Є. Нахлік, Рожанський (Рожаньскій) Гнат, [в:] Шевченківська енциклопедія: в 6 m., т. 5, Київ 2014, с. 507.

9 Є. Нахлік, Танячкевич Данило Іванович, [в:] Шевченківська енщиклопедія: в 6 m., т. 6, Київ 2014, с. 24-25.

10 О. Барвінський, Спомини з мого життя, упор. А. Шацька, О. Федорук; ред. Л. Винар, І. Гирич, ч. 1-2, Нью-Йорк - Київ 2004, с. 83-84.

11 В. Петрикевич, Істория культу Шевченка серед гімназияльної молодіжи: ювілейна студия, Перемишль [1914], с. IX.
} 
Склалася начебто парадоксальна ситуація, а насправді цілком логічна, зумовлена затримкою українського національного розвитку: поляк не тільки сформулював думку про “національний геній” Шевченка ${ }^{12}$, поета першого ряду для України й усієї Слов' янщини ${ }^{13}$, а й, випередивши українців, подав основні факти біографії мистця, проаналізував усі найважливіші твори, окрім Великого льоху і Марії, зокрема й заборонені в Росії, зупинився на польських перекладах. Звичайно, у цій праці багато помилок і неточностей, однак Василь Маслов видасть біографічний нарис про Шевченка щойно у 1874 р., а Михайло Чалий найповнішу тогочасну біографію поета Жизнь и произведения Тараса Шевченко - 1882 р., приділивши в ній небагато уваги творчості мистця й згадавши працю Г. де Батталії як приклад адекватного прочитання поеми Гайдамаки ${ }^{14}$.

Отже, книжка Г. де Батталії є першою спробою літературного портрету Шевченка, що носить не тільки інформативний, а й полемічний характер щодо рецепції Шевченка, передусім польської й імпліцитно про майбутнє української нації. Григорій Вервес слушно підкреслив, що переоцінити цю працю “важко, якщо мати на увазі, що на той час література про Шевченка була незначна, і автор мусив проявити неабияку самостійність в судженнях, намагаючись розкрити сутність поета за його творами" ${ }^{\prime \prime}$. Оскільки твори Шевченка були на той час маловідомими Г. де Батталія часто переказував їхній зміст, подаючи цитати у польських перекладах, а за відсутності перекладу - латинською транслітерацією. Саме він став одним із перших імпліцитних читачів Шевченка, йому вдалося зрозуміти основні ідеї поета, виявивши ті спонуки, що рухали мистцем. Важливо: Г. де Батталія на відміну від багатьох українських інтелектуалів, наприклад, П. Куліша, Михайла Драгоманова чи братів Андрія і Миколи Стороженків, які уважали, наче у Шевченка був недостатній рівень освіти, переносив акцент з особистості митця на його оточення. Він зауважив, що у Східній Європі на відміну від Західної меценати рідко підтримували талановитих людей, сприяючи їхньому розвиткові, навпаки, у цій частині світу талант часто був причиною морального приниження, наприклад, Шевченко мав украсти олівця, щоб мати чим малювати ${ }^{16}$. Заслугою Г. де Батталії є те, що він був одним із перших дослідників, хто підкреслив, що геній Шевченка розвивався всупереч, а не завдяки обставинам.

\footnotetext{
G. Battaglia, Taras Szewczenko, życie i pisma jego, Lwów 1865, c. 8.

Там само, с. 12.

М. Чалый, Жизнь и произведения Тараса Шевченка: (свод материалов для его биографии), Киев 1882, с. 248-249.

15 Г. Вервес, Т. Г. Шевченко і Польщза, Київ 1964, с. 155.

16 G. Battaglia, Taras Szewczenko, życie i pisma jego, Lwów 1865, s. 12.
} 
Виклад біографії і розгляд творчості Шевченка польського автора грунтується на схемі, яку запропонував Олександр Лазаревський ${ }^{17}$, виділивши у життєписі поета п'ять періодів: дитинство (1814-1828), життя у поміщика (1828-1838), вільне життя (1838-1847), заслання (1847-1857), повернення із заслання $(1857-1861)^{18}$. Розповідь польського критика про дитинство Шевченка також базується на вище згаданій статті. Вслід за О. Лазаревським він пише, що майбутній поет народився у Моринцях (передає цю назву як Можиньці), а не в Керелівці, згадує романтичну історію про пошуки малим Тарасом залізних стовпів, повторює помилку О. Лазаревського про те, наче у Шевченка було двоє братів і дві сестри, коли насправді у нього було двоє братів і три сестри. Як і його попередник, наголошує на втраті Тарасом матері, постійних сварках та бійці в хаті Шевченків після появи мачухи, зупиняється на драматичній істоpiї про вкрадені у квартиранта-солдата гроші, коли провину за крадіжку несправедливо приписали Тарасові, криївку, що ï хлопець облаштував у сусідському садку селянина Жениха, про смерть батька і його заповіт, цитує вслід за О. Лазаревським вірш $А$. О. Козачковському, згадує про шапку на зразок конфедератки, яку Тарас пошив собі сам і про всі етапи Тарасової науки у міщанина Губського і дяка Богорського (помилково називає його за О. Лазаревським Бугорським), наголошуючи на таких рисах характеру майбутнього поета, як впертість, незалежність, розвинена уява, боротьба за особисту свободу. Частково ці біографічні факти повторив і Михайло Чалий зі слів Івана Сошенка в статтях в “Основі”, але без тих цікавих деталей, які зустрічаємо в О. Лазаревського і І. де Батталії, наприклад, про конфедератку чи сад Жениха. Звільнення з кріпацтва критик подає за автобіографією Шевченка для редактора "Народного чтения". Зі спогадів І. Сошенка, записаних М. Чалим, Г. де Батталія довідався про те, що Шевченко занедбав науку в Академії мистецтв і розладнав одруження свого товариша з німкенею Марією Іванівною Европеус. Інформацію про розгром Кирило-Мефодіївського братства, зрадника Петрова й заслання Шевченка, зокрема про його перебування у Новопетровському укріпленні автор запозичив зі щоденника Я. Гордона ${ }^{19}$ і $з$ ли-

17 А. Лазаревский, Материаль для биографии Т. Г. Шевченка, “Основа” 1862, № 3, c. 1-10. Цю статтю польський критик згадав у своїй праці на 47 сторінці. Він читав іï і за передруком у часописі “Вечерниці”. Див.: А. Лазаревській, Дитинній вік Шевченка (1814-1828), “Вечерниці” 1863, № 7, с. 55-56; № 8, с. 63-64; № 9, с. 71-72.

18 Це зауважила ще В. Смілянська. Вона відзначила, що польський критик слушно поділив вільне життя Шевченка на період 1838-1843 й так званий київський 1844-1847, повторивши помилку М. Чалого про закінчення Шевченком Академії мистецтв 1844 р. Див: В. Смілянська, Біографічна шевченкіана (1861-1981), Київ 1984, с. 41.

19 Я. Гордон, Солдат, або шість років в Оренбурзі та Уральську, [в:] Рецепиія творчості Тараса Шевченка в Польщі: у 3 кн., кн. 1, Київ 2015, с. 119-120. Дещо ширші 
ста мистця до Я. Кухаренка від 1 квітня 1854 р., який було опубліковано у 10 числі “Основи” за 1861 р., про що згадано у тексті. Ознайомившись iз редакційною приміткою до поеми Кавказ, що була надрукована в часописі "Вечерниці" 20 , він уважав, що саме цей твір був причиною Шевченкового нещастя. Інформація Я. Гордона була істотною для Г. де Батталії, який, як і Я. Гордон, помилково називав Новопетровське укріплення, в якому перебував Шевченко, Маршлак замість Мангишлак. Польський критик був ознайомлений зі щоденником Шевченка, йому відоме було точне датування цього журналу: червень 1857 - липень 1858. На його підставі заторкнув і проблему пияцтва поета, уважаючи, що цей недолік був зумовлений засланням, браком товариства, роботи, відірваністю від батьківщини, бідністю Шевченка-солдата. Цю інформацію підтверджує й лист Шевченка до Я. Кухаренка від 22 квітня 1857 p. ${ }^{21}$ Автор першого літературного портрету Шевченка назвав становище поета на засланні нестерпним, а його душевний стан - розпачливим. Польський критик, мабуть, читав бодай частково щоденник мистця, опублікований у 5-9, 11-12 числах “Основи” за 1861 р. та в 1-8 за 1862 р. Біографічну канву (хай схематичну) від звільнення з солдатчини і до прибуття поета до Москви, згодом і Петербурга реконструював саме за щоденником. Важливим джерелом інформації для Г. де Батталії були листи Тараса до його родича Варфоломія Шевченка (1859-1861), уміщені в другій подачі статті М. Чалого 22 . На підставі цих листів критик писав про плани поета переселитися в Україну, купити землю, збудувати власний дім й одружитися 3 селянкою Харитою. Останнє прагнення мистця дивувало Г. де Батталію не менше, ніж Варфоломія, бо обоє усвідомлювали, що селянка не могла зрозуміти українського пророка. 3 листів Шевченка до Варфоломія автор польської праці дізнався й про наречену поета Ликеру Полусмак, котра виявилася ще гіршою за Хариту, бо попри те, що вміла читати, відзначалася грубою та нешляхетною поведінкою. За матеріалами другої статті М. Чалого в “Основі” Г. де Батталія відтворив приїзд Шевченка до Керелівки після звільнення із заслання, його зустріч із сестрою Яриною і перебування в Корсуні у В. Шевченка. Останні дні життя поета висвітлено за статтею К. Климковича, що була переробкою публікації Льва Жем-

\footnotetext{
відомості про братство зустрічаємо в Спогадах з моєї молодості Г. Батталії, в яких він порівняв братчиків із польськими філаретами. Див.: Г. Баттаглія, Спогади з моєї молодості, [в:] Рецепиія творчості Тараса Шевченка в Польщі: у 3 кн., кн. 1, Київ 2015, с. 18].

20 У примітці сказано: “3 жалю за своїм другом написав Шевченко поему Кавказ, за котору цар Миколай оддав его в солдати на вічні часи, 1847 року”. Див.: “Вечерниці” 1863, № 13 , c. 98.

21 Листи Шевченка, “Основа” 1861, № 10, с. 7.

22 Ч. Сава, (Новые) Материаль для биографии Т. Г. Шевченка, “Основа” 1862, № 6, с. $5-25$.
} 
чужникова про останні дні і похорон українського пророка: польський автор згадав і про лікаря Барі, і про вітальну депешу, яку на свій день народження мистець отримав із Харкова.

3 ранніх творів поета Г. де Батталія особливу увагу звернув на антипольські поеми Тарасова ніч та Гайдамаки, дійшовши висновку, що поет не реабілітовував гайдамаків, а подавав історичні факти так, як їх розумів український народ і пояснювала традиція. На його думку, антипольський рух українського козацтва був наслідком польської релігійної нетолерантності. Водночас публіцист не обійшов мовчанкою і виродження українського козацтва, яке деморалізувалося, воюючи 3 невинними польськими жінками і дітьми. Головним текстом, 3 яким полемізував Г. де Батталія, була рецензія Ф. Фаленського на студію Л. Совінського і його переклад поеми Гайдамаки. Ф. Фаленський доводив, що Шевченко був селянським Байроном навиворіт, послідовником Герострата, зорієнтованим на руїну. У цій рецензії згадувався й П. Куліш, що начебто виправдовував Шевченкове потрактування гайдамаччини, тому рецензія Ф. Фаленського швидше за все була й одним із джерел Мальованої гайдамаччини П. Куліша. Г. де Батталія все ж відчув упередженість рецензента, який і в питаннях Шевченкової біографії не відзначався об'єктивністю, зокрема засуджував панського служку за те, що той, захопившись малюванням, ледве не спалив своєму панові хату в Вільні. Про цей епізод 3 життя Шевченка обидва польські критики дізналися 3 автобіографії Шевченка, написаної для редактора журналу “Народное чтение”. Л. Совінський переклав цю автобіографію й умістив у власній студії ${ }^{23}$. Ф. Фаленський писав, наче життя Шевченка після викупу із кріпацтва ішло, як по маслу ${ }^{24}$, він не згадав про заслання поета і вирок йому царя Миколи I. 3 нинішньої перспективи такий спосіб подачі матеріалу можна розцінювати як маніпуляцію, яку демаскував І. де Батталія, подаючи біографію українського мистця без лакун. Польський критик також підкреслив, що у поемі Гайдамаки поет не закликав своїх читачів до помсти ворогові, а мав на меті правдиво розповісти про перебіг подій, щоб застерегти обидві сторони конфлікту. Аналогічно, за Г. де Батталією, поему Тарасова ніч не можна називати “канібальською епопеєю”. Цього разу він полемізував уже 3 Л. Совінським, який писав, наче ця поема “вирвалася не 3 грудей людини, а 3 горла ворона" 25 . Образ круків, що у тексті Шевченкової пое-

23 T. Szewczenko. Studium przez Leonarda Sowińskiego z dołaczeniem przekładu Hajdamaków, Wilno 1861, c. V-XV.

${ }_{24}$ F., Taras Szewczenko, studyum przez Leonarda Sowińskiego, z dołaczeniem przekładu Hajdamaków. Wilno, nakładem Michała Gałkowskiego, 1861, "Biblioteka Warszawska" 1862, T. 1, c. 162.

${ }_{25}$ T. Szewczenko. Studium przez Leonarda Sowińskiego z dołaczeniem przekładu Hajdamaków, Wilno 1861, c. LIII. 
ми налетіли “вельможних будити”, перекладач трактував як канібалізм. Г. де Батталія заперечував таке розуміння. На його думку, поет оплакував кровопролиття, але при цьому показував історію з української сторони, використовуючи традиційні (фольклорні) образи. Водночас критика обурила негативна характеристика у поемі Гайдамаки конфедератів, людей шляхетних і шляхтичів. Він назвав цей сюжет пасквілем, в якому захисники Польщі постають звичайнісінькими грабіжниками. 3 його точки зору, в цьому виявилася легковажність Шевченка, бо в такий спосіб поет розпалював в українських селянах ненависть до поляків, а така тактика $\epsilon$ неприпустимою для освіченої людини. Окремо наголосив і на такому анахронізмі, як згадка у зв'язку з конфедератами пісні 1797 р. "Мазурка Домбровського”. Автор літературного портрету не взяв до уваги, що карикатура була близькою Шевченкові, який у своїй творчості вдавався не тільки до іронії, а й до сатири, сарказму, гротеску. Карикатурними у його поезії постають не тільки цар Микола I і його дружина Олександра Федорівна, карикатурними рисами наділений не тільки Петро I (чи радше пам'ятник імператору), Катерина II, а й Богдан Хмельницький, оточення останнього гетьмана Кирила Розумовського, уся зрусифікована українська еліта і навіть носії української пам'яті - кобзарі.

Щодо промови благочинного, то Г. де Батталія інакше, ніж Шевченко, дивився на причини кривавого 1768 р., наголосивши на втручанні Росії: “Причиною тих убивств були московські рублі” 26. При цьому критик на відміну від Я. Гордона твердив про неоднорідність гайдамацького середовища: Іван Гонта, на його думку, не брав російських грошей. Найголовніше: Г. де Батталія дійшов висновку, що хай поема Гайдамаки не надто поетична, але ії значення переростає поезію, бо вона є твором для українського народу, який сприймає її серцем, почуттями ${ }^{27}$. Загалом найдовершенішим раннім твором Шевченка критик уважав Катерину, полемізуючи з А. Гожалчинським щодо значення слова “москаль” у цій поемі, доводячи, що Шевченко мав на увазі не солдатів, а росіян. 3 цієї причини й Москалеву кринищю переклав як Солдатська криниия. Щодо творів на історичну тему, то найдовершенішим 3-поміж них уважав $Г a-$ малію. Подібну оцінку цій поемі дав і Ф. Фаленський в іншій своїй рецензії на переклад Кобзаря В. Сирокомлі, що була опублікована у тому ж часописі "Biblioteka Warszawska", але вже у 1 числі за 1863 р. Про неї І. де Батталія у своїй праці не згадав, можливо, тому, що його оцінка поем Катерина і Наймичка не надто відрізнялася від оцінки Ф. Фаленського. Різниця полягала в тому, що останній надавав перевагу Наймичиі перед Катериною.

26 G. Battaglia, Taras Szewczenko, życie i pisma jego, Lwów 1865, c. 35.

27 Там само, с. 40. 
Твори, написані Шевченком до арешту Кирило-Мефодіївського братства, Г. де Батталія назвав київськими і вільнодумними. У них, за його спостереженням, поет декларував власні політичні засади. До цього періоду він відніс такі твори, як Невольник (це редакція 1859 р. поеми 1845 p. Сліпий, про що критик не знав), Кавказ, Сон - У всякого своя доля, Холодний яр, Чигрине, Чигрине..., окремо Суботів і послання I мертвим, $i$ живим.... Саме ці тексти він назвав "дзеркалом душі поета"28. Згадав він і поему Ян Гус (Сретик), у 1 числі Основи за 1860 р. було опубліковано її уривок - Посланіє Шафарикові. У поемі Кавказ польський критик відмітив релігійну толерантність Шевченка, зазначивши, що й до своєї віри мистець був прив'язаний ${ }^{29}$, хоча й не розумів, що вістря критики Шевченка у цій поемі було спрямоване проти російського варіанту православія. Сцену “генерального мордобитія” з поеми Сон Г. де Батталія порівняв із закінченням поеми Адама Міцкевича Дзяди, зауваживши, що Шевченковому твору бракує художньої глибини польського пророка. Однак й попри відсутність, у його розумінні, духовного лету відзначив прості й живі образи поеми ${ }^{30}$. Про велич українського літератора, на його думку, свідчать два твори - поема Катерина й Сон - У всякого своя доля. У першому вражає мистецьке виконання, у другому - поетична фантазія мистця. В обох творах наявні великі ідеї. У таких творах, як Чигрине, Чигрине..., Суботів і Холодний яр польський автор акцентував на Шевченковій антипатії до ляхів і москалів, а також на його ідеалі незалежної і вільної України. Послання I мертвим, і живим... оцінив не надто високо, зазначаючи, що в інших творах думка про служіння вітчизні висловлена досконаліше. Попри цей недостатньо аргументований висновок, бо критик не назвав жодного іншого твору на згадану тему, він все ж відмітив у посланні сильний критичний пафос щодо невірних синів України, дидактизм і моралізаторство без жодних поетичних прикрас. Польський автор дійшов висновку, що у творах періоду “трьох літ”, зокрема в поемах Кавказ і Сон поет відмовився від народних форм, тому українському селянському загалові зрозуміти мистця було складно. Високо натомість поставив поему Невольник, що була вперше опублікована в 4 числі "Основи” за 1861 р. 3 творів періоду заслання детально зупинився на поемі Чернець, яку прочитав у 3 числі часопису "Вечерниці" за 1863 р. Передрук твору було зроблено з першого номера "Основи" за 1861 р. В обох була присвята П. Кулішу, про що не забув поінформувати своїх читачів Г. де Батталія.

Там само, с. 41.

Там само, с. 43.

Там само, с. 45. 
Про російські твори українського пророка критик дізнався зі статті М. Лазаревського про прозаїчні твори Шевченка російською мовою, в якій був перелік усіх російських повістей з Повістю про безродного Петруся включно ${ }^{31}$. Уживання поетом російської мови трактував як наслідок заслання, коли над поетом здійснювався постійний нагляд ${ }^{32}$. Уважав, що після повернення з заслання Шевченко вже не сягнув вершин свого мислення, але створив кілька довершених творів. Критик проаналізував поеми Неофіти, Москалева криниия, також Вiдьму, яку помилково відніс до позасланчого періоду Шевченкової творчості й переклав як Привид. Найнижче оцінив Москалеву криницю, не спостерігши у цьому творі якоїсь виразної моральної, політичної чи соціальної думки. Окремо спинився на Предсмертних думах Шевченка, з якими ознайомився у 5 і 6 числі "Основи” за 1861 р. У цьому циклі було зібрано ліричні вірші, написані після повернення поета із заслання до Петербурга, зокрема й останній Чи не покинуть нам, небого..., який Г. де Батталія згадав без назви. Критик писав, що в цих ліричних віршах особливу роль відіграють почуття, але $\epsilon$ в них і глибокі філософські роздуми ${ }^{33}$. Окрему увагу приділив Давидовим псалмам, які читав у Кобзарі (1860), перелічивши у своїй праці всі твори, що увійшли до останнього прижиттєвого видання Шевченка. Він полемізував із Л. Совінським, котрий писав, наче перекладені Шевченком псалми хоча й майстерні, проте лякають читача ${ }^{34}$. Г. де Батталія зазначив, що не знає, як реагувати на твердження, наче якийсь із псалмів царя Давида нагонить на читачів страх ${ }^{35}$. Також він помітив, що цензура у багатьох місцях вилучила з псалмів небажаний текст, про що свідчать крапки. Критик мав на увазі пропуски в псалмах Боже, нашими ушима, Пребезумний в сериі скаже, Меж ияарями-судіями, На ріках круг Вавилона.

Праця Г. де Батталії прислужилася не тільки іншим дослідникам творчості Шевченка, зокрема В. Маслію, М. Чалому, Й.-Г. Обрістові, а й передусім галицькій молоді. Щоб належно пізнати пророка, критик радив полякам читати Шевченка гражданкою, уважав, що пізнати поета важливо, оскільки цей мистець $є$ носієм нової української ідентичності, ідентичності, яку приміряють на себе інтелігентні українці, зокрема українці-галичани, переважно семінаристи. Зрозуміло, що при цьому автор праці уживав етнонім “русин”. Польський критик не тільки відчув,

\footnotetext{
31 М. Лазаревский, Извещение о прозаических сочинениях Т. Г. Шевченко на великорусском языке, „Основа” 1862, № 3, с. 142-143.

32 G. Battaglia, Taras Szewczenko, życie i pisma jego, Lwów 1865, s. 48.

33 Там само, с. 55.

34 T. Szewczenko. Studium przez Leonarda Sowińskiego z dołaczeniem przekładu Hajdamaków, Wilno 1861, c. XLVIII.

35 G. Battaglia, Taras Szewczenko, życie i pisma jego, Lwów 1865, c. 54.
} 
що поезія Шевченка $є$ майстерною, не тільки першим намагався показати творчість українського поета на тлі його біографії й в історичному контексті, а й розгледів той “горизонт сподівань”, який був закритим для багатьох зрусифікованих або й сполонізованих етнічних українців у др. пол. XIX ст. - горизонт української ідеї.

\section{БІБЛІОГРАФІЯ}

Barvìns'kij Oleksandr. 2004. Spomini z mogo žittâ. Red. Vinar L., Girič Ì. N'û-Jork-Kiïv: Smoloskip. Č. 1-2 [Барвінський Олександр. 2004. Спомини з мого життя. Ред. Винар Л., Гирич І. Нью-Йорк-Київ: Смолоскип. Ч. 1-2].

Battaglia baron Gwido. 1865. Taras Szewczenko, życie i pisma jego. Lwów: Nakładem redakcji «Tygodnika Naukowego».

Č. Sava. 1862. (Novye) Materialy dlâ biografii. G. Ševčenka. "Osnova" nr 5: 45-61 [Ч. Сава. 1862. (Новые) Материаль для биографии Т. Г. Шевченка. "Основа” № 5: 45-61].

Č. Sava. 1862. (Novye) Materialy dlâ biografiit. G. Ševčenka. "Osnova” nr 6: 1-27 [Ч. Сава. 1862. (Новые) Материаль для биографии Т. Г. Шевченка. "Основа” № 6: 1-27].

Čalyj M. K. 1882. Žizn' i proizvedeniâ Tarasa Ševčenka: (svod materialov dlâ ego biografii). Kiev: Tipografiâ К. N. Milevskogo [Чалый М. К. 1882. Жизнь и произведения Тараса Шевченка: (свод материалов для его биографии). Киев: Типография К. Н. Милевского].

F. 1862. Taras Szewczenko, studyum przez Leonarda Sowińskiego, z dołaczeniem przekładu Hajdamaków. Wilno, nakładem Michała Gałkowskiego, 1861. "Biblioteka Warszawska" T. 1: 159-163.

Gorzałczyński Antoni J. 1862. Przekłady pisarzów małorossyjskich. T. 1: Taras Szewczenko. Kijów: Nakładem T. Maracewicza.

Kobzarz Tarasa Szewczenki / z małorossyjskiego spolszczył Władysław Syrokomla. 1863. Wilno: Nakładem A. ASSA.

Ks. Kl. 1862. Zgadka za Ševčenka; ego smert' i pohorony: Pôslâ L. Žemčužnikova. "Večernici”" nr 22: 193-197 [Кс. Кл. 1862. Згадка за Шевченка; его смерть и похороны: Поссля Л. Жемчужникова. “Вечерниці” № 22: 193-197].

Lazarevskij Aleksandr. 1862. Detstvo Ševčenka (1814-1828): Materialy dlâ biografii T. G. Ševčenka. "Osnova” nr 3: 1-10 [Лазаревский Александр. 1862. Детство Шевченка (1814-1828): Материалы для биографии Т. Г. Шевченка. “Основа” № 3: 1-10].

Lazarevskij Mihail. 1862. Izveŝenie o prozaičeskih sočineniâh T. G. Ševčenko na velikorusskom âzyke. “Osnova” № 3: 142-143 [Лазаревский Михаил. 1862. Извещение о прозаических сочинениях Т. Г. Шевченко на великорусском языке. "Основа” № 3:142-143].

Lazarevs'kìj. 1863. Ditinnìj vik Ševčenka (1814-1828). "Večernicì” № 7: 55-56; № 8: 63-64; № 9: 71-72 [Лазаревській. 1863. Дитинній вік Шевченка (1814-1828). “Вечерниці” № 7: 55-56; № 8: 63-64; № 9: 71-72].

Listi Ševčenka. 1861. “Osnova” № 10: 3-16 [Листи Шевченка. 1861. “Основа” № 10: 3-16]. 
Nahlik Êvgen. 2014. Rožans'kij (Rožan'skij) Gnat. V: Ševčenkìv'ka enciklopediâ: $v 6 t$. T. 5. Kiïv: NAN Ukraïni, İn-t l-ri ìm. T. G. Ševčenka: 506-507 [Нахлік Євген. 2014. Рожанський (Рожаньскій) Гнат. В: Шевченківська енциклопедія: в 6 m. Т. 5. Київ: НАН України, Ін- $m$ л-ри ім. Т. Г. Шевченка: 506-507].

Nahlik Êvgen. 2014. Tanâčkevič Danilo İvanovič. V: Ševčenkivs'ka enciklopediâ: $v 6 t$. T. 6. Kiïv: NAN Ukraïni, İn-t 1-ri ìm. T. G. Ševčenka: 24-25 [Нахлік Євген. 2014. Танячкевич Данило Іванович. В: Шевченківська енциклопедія: в 6 m. Т. 6. Київ: НАН України, Ін- $m$ л-ри ім. T. Г. Шевченка: 24-25].

Petrikevič V. [1914]. İstoriâkul'tu Ševčenka sered gìmnaziâl'noï molodiži: ûvilejna studiâ. Peremišl': z drukarnì gr. kat. Kapituli [Петрикевич В. [1914]. Істория культу Шевченка серед гімназияльної молодіжи: ювілейна студия. Перемишль: $з$ друкарні гр. кат. Капітули].

Radiševs'kij Rostislav (Red.). 2015. Recepciâ tvorčostì Tarasa Ševčenka v Pol'sì: u 3 kn. Kn. 1. Kiïv: Unìversitet «Ukraïna» [Радишевський Ростислав (Ред.). 2015. Peиепиія творчості Тараса Шевченка в Польщі: у 3 кн. Кн. 1. Київ: Університет «Україна»].

Ševčenko Taras. 1860. Kobzars 'kij gostinec'. V: “Hata”. Peterburg: v drukarnì P. A. Kulìša: 73-90 [Шевченко Тарас. Кобзарський гостинець. В: "Хата”. Петербург: в друкарні П. А. Куліша: 73-90].

Smìlâns'ka Valeriâ. 1984. Biografična ševčenkiana (1861-1981). Kï̈v: Naukova dumka [Смілянська Валерія. 1984. Біографічна шевченкіана (1861-1981). Київ: Наукова думка].

Smìlâns'ka Valerìâ. 2013. Battaliâ Gìido de. V: Ševčenkìv'ka enciklopedîa: v 6 t. T. 1. Kiïv: NAN Ukraïni, İn-t 1-ri ìm. T. G. Ševčenka: 345-346 [Смілянська Валерія. 2013. Батталія Гвідо де. В: Шевченківська енциклопедія: в 6 m. Т. 1. Київ: НАН України, Ін-m л-ри ім. T. Г. Шевченка: 345-346].

Taras Szewczenko: studium przez Leonarda Sowińskiego z dołaczeniem przekładu Hajdamaków. 1861. Wilno: Nakładem M. Gałkowskiego,

Verves Grigorìj. 1964. T. G. Ševčenko ì Pol'ŝa. Kï̈v: Dnìpro [Вервес Григорій. 1964. Т. Г. Шевченко і Польща. Київ: Дніпро].

Žemčužnikov Lev. 1861. Vospominanie o Ševčenke, ego smerti i pogrebenii. "Osnova" $\mathrm{nr}$ 3: 1-21 [Жемчужников Лев. 1861. Воспоминание о Шевченке, его смерти и погребении. “Основа” № 3: 1-21].

\section{ŹRÓDŁA PRACY GWIDO DE BATTAGLII NA TEMAT SZEWCZENKI}

Streszczenie: Artykuł wyjaśnia, że zanim była opublikowana jako osobny druk, praca G. de Battaglii Taras Szewczenko, życie i pisma jego została wydana pod nazwą Szewczenko, poeta ukraiński w numerach 1-7, 9-11, 13-18 „Tygodnika Naukowego” we Lwowie w 1865 r. Artykuł analizuje źródła używane przez polskiego krytyka. Autor konkluduje, że w świetle ograniczonego materiału biograficznego i literackiego na temat Szewczenki i jego twórczości G. de Battaglia wykazał się niezależnością myślenia i obiektywizmem sądów na podstawie poetyckich dzieł ukraińskiego poety, w tym także tych zakazanych w Rosji. Jego praca ma zarówno charakter informacyjny, jak i polemiczny. Krytyk spierał się najpierw z F. Faleńskim, częściowo z L. Sowińskim, solidaryzował się natomiast z J. Lamem w sprawie kształtowania nowej tożsamości ukraińskiej oraz w sprawie znaczenia Szewczenki w tym procesie. Pomimo błędów i nieścisłości to dzięki tej pracy młode 
pokolenie galicyjskich Ukraińców w latach 60 -ych XIX wieku poznało biografię i twórczość Szewczenki.

Słowa kluczowe: Gwido de Battaglia, Szewczenko, pierwsze studium Szewczenkowskie, portret literacki, źródła, charakter informacyjny i polemiczny, tożsamość ukraińska.

\section{ДЖЕРЕЛА ПРАЦІ ГВІДО ДЕ БАТТАЛІЇ ПРО ТАРАСА ШЕВЧЕНКА}

Анотація: У статті зроблено уточнення щодо першодруку праці Гвідо де Батталії Тарас Шевченко, його життя і твори. Перш ніж вийти окремим відбитком вона друкувалася під назвою Шевченко, украӥнський поет у 1-7, 9-11, 13-18 номерах львівського часопису “Tygodnik Naukowy” за 1865 р. Доповнено джерела, якими користувався польський критик. Авторка доходить висновку, що у зв'язку з обмеженим біографічним й літературознавчим матеріалом на тему Шевченка і його творчості І. де Батталія виявив самостійність мислення й об'єктивність суджень на підставі поетичних творів українського поета, зокрема й заборонених в Росії. Його праця носить як інформативний, так і полемічний характер. Критик полемізував передусім з Ф. Фаленським, частково з Л. Совінським, солідаризуючись з Я. Лямом у питанні формування нової української ідентичності й у питанні значення Шевченка в цьому процесі. Попри ряд помилок і неточностей саме завдяки цій праці з життям і творчістю Шевченка знайомилося молоде покоління галицьких українців у 1860-х рр. й читачі-поляки.

Ключові слова: Г. де Батталія, Шевченко, перша шевченкознавча праця, літературний портрет, джерела, інформативний і полемічний характер, українська ідея. 
